\title{
真空絶縁破壊に打ける電極材料元素及び酸素の 発光スペクトルの観測*
}

小林 信一 $* *$. 細田 稔**.斉藤 芳男 $* * *$

（受付1991年12月 2 日，掲載決定1992年 2 月 8 日）

\author{
Observations of Optical Spectra of Electrode Materials \\ and Oxygen Emitted from Vacuum Gaps under Breakdown \\ Shinichi KOBAYASHI, Minoru HOSODA and Yoshio SAITO \\ **(Department of Electrical Engineering, Saitama University, Urawa, Saitama) \\ *** (National Laboratry for High Energy Physics, Tsukuba, Ibaraki) \\ (Received December 2, 1991, Accepted February 8, 1992)
}

\section{1.はじめに}

真空ギャップの絶縁破壊は, 電極材料の金属蒸気およ び不純物ガスなどがギャップ間に放出され，それらがイ オン化することにより発生すると考它られている. 本研 究では不純物ガスとして酸素に注目し，絶縁破壊時の電 極材料と酸素の発光スペクトルを観測して絶縁破壊回数 に対する各元素のスペクトル強度の変化及び絶縁破壊電 界の変化を調べた。電極材料は, $\mathrm{Cu}, \mathrm{Fe}$, 及び $\mathrm{Al}$ の 3 種類である.

\section{2. 実験装置・方法}

Fig. 1 亿実験装置図を示す，大別してインパルス発生 器（波頭長 $64 \mu \mathrm{s}$, 波尾長 $700 \mu \mathrm{s}$, 最大尖頭電圧 $100 \mathrm{kV}$ ) 真空容器, 分光器 (回析格子型), 光電子増倍管 (サイ ドオン型 $1 \mathrm{P} 28 \mathrm{~A})$, データ取り込み用のパーソナルコン ピューターからなる. 光電子増倍管は 2 本用意し, 2 本 のスペクトル線を同時に観測できる。試料電極は大気中 で超音波洗浄を施した後, 真空容器内に固定し容器内を $1 \times 10^{-6} \mathrm{~Pa}$ 以下まで排気する. その後電極間にインパ ルス高電圧を印加し絶縁破壊させる.

* 平成 3 年 10 月 31 日 第32回真空に関する連合講演会で発表

** 埼玉大学丁学部電気丁学科（开338 浦和市下大久保255）

***高エネルギー物理学研究所（开305 つくぱ市大穗 1-1）
発光スペクトル強度の観測の準備のため, まず, 電極 間で発するスパーク光のスペクトルをフィルム （Kodak-TRIX）に記録し, 発光元素の同定を行った ${ }^{1)}$. 次に, そのうちの電極材料と酸素の中の 1 本の計 2 本の スペクトル線の位置に光電子増倍管を合わせ, 500 回く り返し絶縁破壊させて絶縁破壊回数に対する絶縁破壊電 界の変化及びスペクトル強度の変化を調べた。

以上の実験を $\mathrm{Cu}$ 電極（純度 $99.9 \%$ ） $\mathrm{Fe}$ 電極（同 99.5\%) Al 電極（同99.99\%）について行った.

\section{3. 実験結果・検討}

3 種類の電極について発光スペクトルを観測し，波長 を同定したところ，電極材料元素のスペクトル線の他に， $\mathrm{Cu}$ については酸素のスペクトル線 $(407.6 \mathrm{~nm}, 459.6$ $\mathrm{nm}, 466.2 \mathrm{~nm}$ ) が観測された。 そこで, 酸素を不純物 ガスとしてとらえ, 比較的強度の高かった $466.2 \mathrm{~nm} の$ スペクトル線をその後のくり返し絶縁破壊実験中の測定 対象として選択した. また，電極材料元素のスペクトル 線として $\mathrm{Cu}: 510.6 \mathrm{~nm} \mathrm{Fe}: 527.0 \mathrm{~nm} \mathrm{Al}: 396.2 \mathrm{~nm}$ の 3 つの波長をそれぞれ選んだ。

Fig. 2 にくり返し絶縁破壊実験の中の波形の一例とし て $\mathrm{Al}$ の100回目の絶縁破壊で得られたものを示した. (a) は電極間の電圧波形である．電圧波形が落ち込んでいる

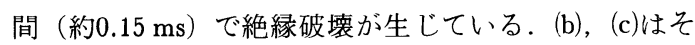




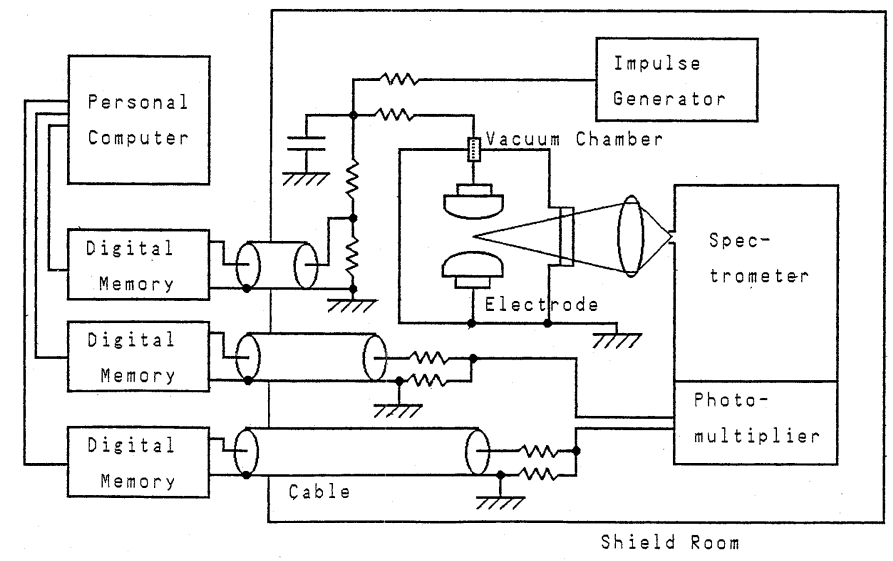

Fig. 1 Schematic Diagram of Experimental System.
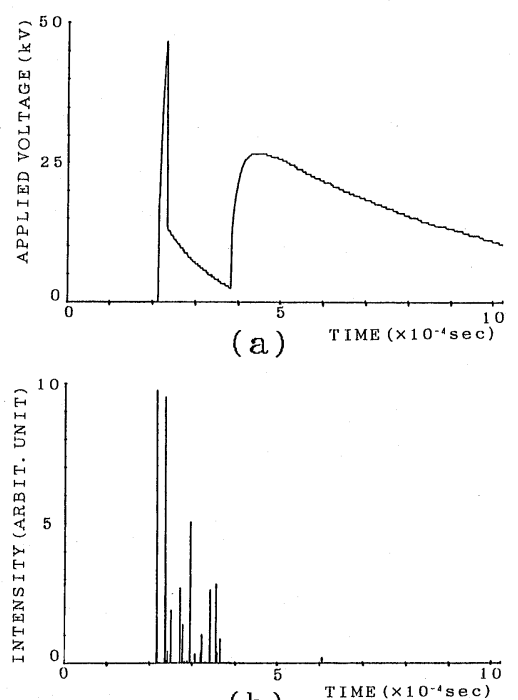

(b)

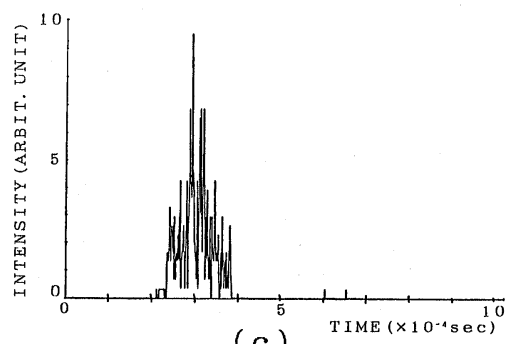

(c)

Fig. 2 Wave Forms obtained at the 100th Breakdown of $\mathrm{Al}$ Electrodes.

(a) Voltage across the Gap

(b) Spectrum of Oxygen

(c) Spectrum of Aluminum
の時の酸素のスペクトル線およびアルミニウムのスペク トル線の強度の時間的変化を示して拈り，それぞれ絶縁 破壊中に同時に発光していることが分かる．(b)では発光 が時間的に飛び飛びであるのに対し(c)では連続的に観測 されているが，これはアルミニウムの発光が酸素の発光 に比べて非常に強いためである。（本実験ではスペクト ル線の発光強度として光電子倍管から出力されるパルス 数を用いた.）

くり返し絶縁破壊を500回行う間に以上のような波形 を随時記録し， 3 種類の電極について Fig. 3 及び Fig. 4 亿示される実験結果がそれぞれ得られた。Fig. 3 は絶 縁破壊回数が 1 回目から 500 回目まで10回毎に絶縁破壊 電界及び電極間隔の変化をプロットしたものである. 電 極間隔が変化しているのは, 絶縁破壊をくり返すとコン ディショニング効果により最大電圧を印加しても絶縁破 壊を起こさなくなるので, 絶縁破壊させるために順次ギ ヤップ長を小さくしたためである. Fig. 4 は絶縁破壊回 数 1 回目から 500 回目まで 50 回毎（300回目からは 100 回 毎）に電極材料元素スペクトルと酸素スペクトルの相対 強度の変化を示したものである. 電極材料元素々酸素の 発光強度（計測されたパルスの数）を加算した值を 1 と して電極材料元素および酸素の発光強度の割合を帯グラ フで示している.

Fig. 3 では 3 種類のいずれの電極材料の場合もコンデ ィショニング効果が認められる.しかし， $\mathrm{Cu}$ の場合は 破壊回数 150 回以降, 破填電界の.上昇が飽和している.

これは, Fig. 4 のように酸素スペクトルの相対強度が $\mathrm{Fe}, \mathrm{Al}$ に比べて高いことと関係があると考えられる. そ こで，まず 1 回目から10回目までの間の絶縁破壊電界の 上昇分を求めると, $\mathrm{Cu}$ は $2.3\left(\times 10^{7} \mathrm{~V} / \mathrm{m}\right.$, 以下同じ $)$, $\mathrm{Fe}$ は3.0, $\mathrm{Al} 1.5$ となり, 以後の絶縁破壊回数のところ 


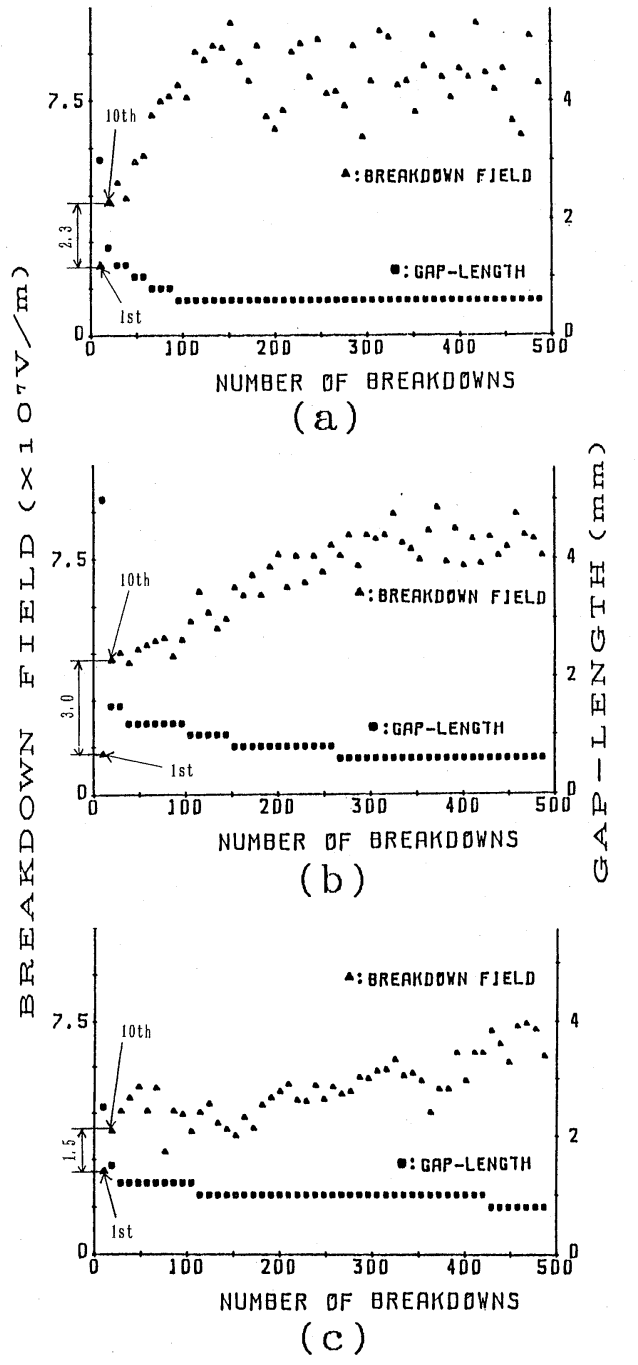

Fig. 3 Dependence of Breakdown Fields on the Number of Breakdowns.
(a) $\mathrm{Cu}$ Electrodes
(b) Fe Electrodes
(c) $\mathrm{Al}$ Electrodes

では見られない上昇を示している. Fig. 4 で 1 回目と50 回目のスペクトルの相対強度の変化をみると $\mathrm{Cu}$ と $\mathrm{Fe}$ については酸素スペクトルの相対強度が減少し, 代わり に電極材料元素スペクトルの相対強度が増加している. 即ち, 絶縁破壊回数が 10 回までは，電極材料よりもむし ろ電極表面に付着している不純物が絶縁破壊の発生を左 右している可能性が高い. 実際，Fig. 5 に示した $\mathrm{Cu}$ の 1 回目の絶縁破壊時の波形では, 酸素スペクトル（実線） が観測された後, 約 $7 \mu \mathrm{s}$ 遅れて Cu スペクトル（破線） が観測されている.電極材料中に含まれている酸素が真

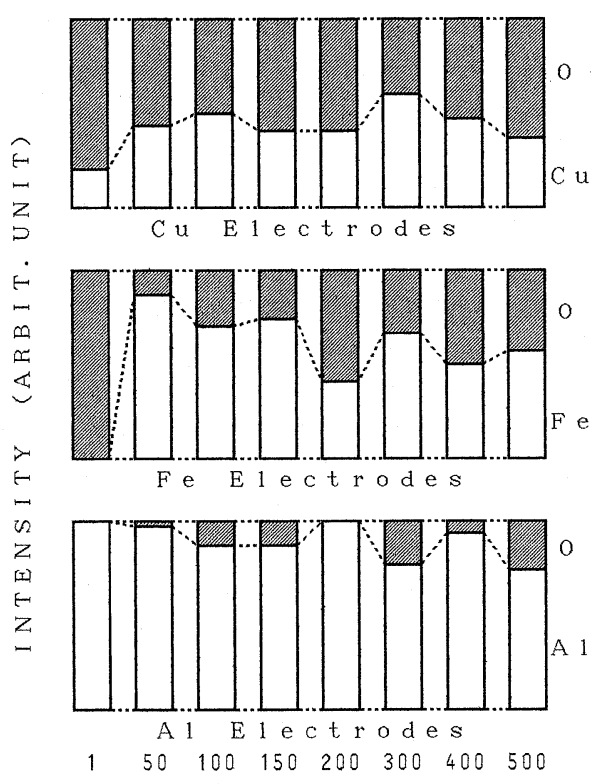

THE NUMBER OF BREAKDOWNS

Fig. 4 Dependence of Spectrum Line Intensity on the Number of Breakdowns.
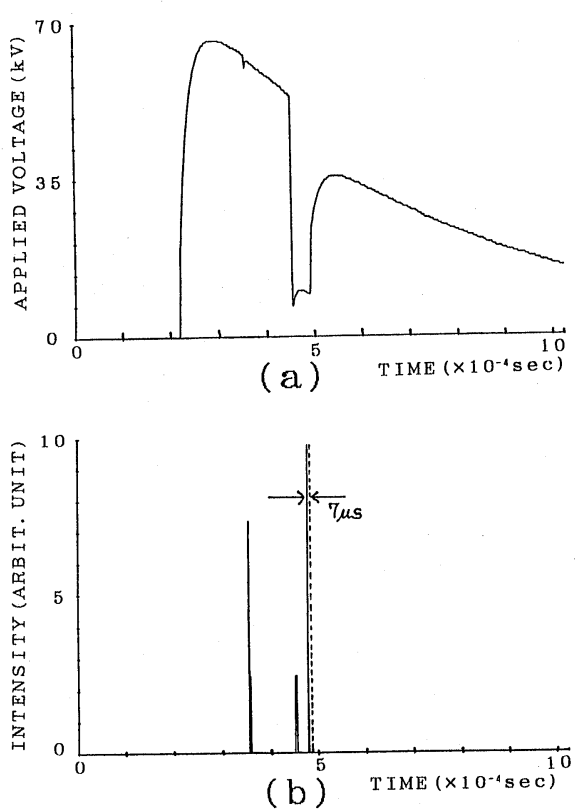

Fig. 5 Wave Forms obtained at the 1st Breakdown of $\mathrm{Cu}$ Electrodes.

(a) Voltage across the Gap

(b) Spectra of Oxygen (Solid line) and $\mathrm{Cu}$ (Broken line) 
空中に脱離して発生するとすれば, Fig. 2 のよらに酸素 と電極材料元素の両方のスペクトルが同時に観測される はずである. 従って, Fig. 5 は電極表面に付着している 不純物（酸素）が絶縁破壊の発生を左右しているといら 推測を裏付けている.

$\mathrm{Al}$ の場合は全絶縁破壊回数500回を通じて酸素スペク トルの相対強度には顕著な変化が見られなかった。この 原因として，Al は $\mathrm{Cu}$ や $\mathrm{Fe}$ に比べて融点が低いため絶 縁破壊が電極材料自身に依存する可能性が $\mathrm{Cu}$ や $\mathrm{Fe}$ よ り高いことが考えられる.

\section{4. ま と め}

真空中の絶縁破壊に打ける発光スペクトルのうち, 電 極材料元素と酸素の 2 つスペクトルに着目して, それ らの相対強度の变化と絶縁破壊電界特性の関係を $\mathrm{Cu}$,
$\mathrm{Fe}, \mathrm{Al}$ の 3 種類の材料の電極について調べた. その結果, 1 回目の破壊と 50 回目の破壊の間で酸素スペクトルの相 対強度が激減し，代わりに電極材料元素スペクトルの相 対強度の増加が見出され，その間の 1 回目から10回目の 絶縁破壊電界の上昇が全500回絶縁破壊を通じて最大で あった。このことから, 絶縁破壊回数が10回程度のコン ディショニング過程の初期の段階では, 電極表面に付着 している不純物が絶縁破壊特性に大きく影響を及ぼすも のと結論つけけらた。

\section{〔文献〕}

1) G. R. Harrison: WAVELENGTH TABLES.

(THE M. I. T. PRESS. 1969). 